\title{
CZECHOSŁOWACJA I REPUBLIKA CZESKA
}

\author{
DWIE NIEPODLEGŁOŚCI I JAN PAWEŁ II
}

W październiku 2018 roku Republika Czeska obchodziła stulecie utworzenia Czechosłowacji. Państwo, które powstało w roku 1918, wyłoniło się z wcześniejszego Cesarstwa Austro-Węgierskiego i dało Czechom i Słowakom poczucie niezależności oraz możliwość decydowania o kształcie własnej państwowości.

Podobne wydarzenia miały miejsce w roku 1989, wtedy powtórnie Czesi i Słowacy odzyskali niepodległość po upadku rządów komunistycznych.

Trzy lata później utworzyli swoje odrębne państwa. Po podziale Czechosłowacji w roku 1993 Czesi i Słowacy zachowali dobre, a nawet przyjacielskie relacje, ale uzyskaną przed stu laty nieodległość świętowali oddzielnie.

W czasie tych znaczących wydarzeń, a więc tworzenia się niepodległej Czechosłowacji w roku 1918 oraz upadku komunizmu w 1989, w sposób zdecydowanie odmienny przejawiła się rola Kościoła katolickiego oraz nastawienie do niego większości społeczeństwa. Pod koniec I wojny światowej spotykał się on raczej z niechęcią i z krytyką, natomiast w roku 1989 okazywano mu uznanie i obdarzano go prestiżem. Przejawami tych zasadniczych różnic może być kilka zjawisk i wydarzeń:

1) 28 października 1918 arcybiskup Pragi przebywał poza miastem i na wieść o powstaniu nowego państwa postanowił nie przyjeżdżać do swojej praskiej siedziby, do końca życia już tam nie przyjechał; w listopadzie 1989 arcybiskup Pragi wracał z Rzymu z kanonizacji św. Agnieszki Czeskiej i zaraz po powrocie w katedrze praskiej wypowiedział znamienne (później często cytowane) słowa: „W tej ważnej godzinie walki o prawdę i sprawiedliwość w naszym kraju ja i Kościół katolicki stoimy po stronie narodu"1.

${ }^{1}$ Por. J. Hanuš, Tradice českého katolicismu ve 20. století, Brno 2005, s. 73; zob. także B. Svoboda, Po stronie narodu. Kardynał František Tomášek w boju z reżimem komunistycznym (1965-1989), Kraków 2013, s. 244. 
2) Pierwszy prezydent Czechosłowacji unikał spotkania z papieżem, T. G. Masaryk będąc w Rzymie, nie odwiedził papieża Benedykta XV², natomiast prezydent Václav Havel już na początku swojej prezydentury zaprosił Jana Pawła II.

3) W czasie rewolucyjnych przemian w dniu 3 listopada 1918 roku tłum zburzył kolumnę Matki Bożej na Rynku Starego Miasta, natomiast w czasie listopadowej rewolucji w roku 1989 podczas jednej z kilkusettysięcznych manifestacji ksiądz katolicki odmawiał modlitwę „Ojcze nasz”.

4) Po roku 1918 powstały nowe Kościoły, szczególnie ważnym wydarzeniem było zwłaszcza powstanie w roku 1920 Kościoła czechosłowackiego, do którego przeszła duża liczba katolików (z czasem prawie milion); po roku 1989 nadspodziewana duża liczba osób identyfikowała się z Kościołem katolickim, w czasie spisu powszechnego w roku 1991 było to 39\% Czechów (w 2001 26,8\%, a 2011 już tylko 10,4\%; liczba z 1989 roku była niespodziewanie duża, zwłaszcza w odniesieniu do liczby osób uczestniczących w niedzielnych nabożeństwach). Inaczej mówiąc po pierwszej wojnie światowej czescy katolicy raczej opuszczali Kościół katolicki, a po listopadowej rewolucji w roku 1989 do niego wracali, wstępowali do niego lub też z nim się utożsamiali nie mając z nim jednak realnych więzi.

\section{Pierwsza niepodległość - 1918}

Z czego wynikały takie różnice w postawach polityków i społeczeństwa w roku 1918 i 1989? Odpowiadając na to pytanie, możemy wskazać przyczyny niechęci czeskiego społeczeństwa do Kościoła katolickiego w okresie międzywojennym:

1) W zbiorowej pamięci Kościół katolicki kojarzony był z rządami Habsburgów, legitymizował władzę tej dynastii, jego struktury były wykorzystane do sprawowania rządów, a jego hierarchia czerpała korzyści z powiązania z organami władzy. Niechęć społeczeństwa czeskiego wynikała zatem z traktowania Kościoła katolickiego jako narzędzia obcego władcy ${ }^{3}$.

2) Józefinizm. W społeczeństwie czeskim było obecne przekonanie, że struktury kościelne są częścią struktur państwowych. Takie przekonanie istniało już przed rządami cesarza Józefa II (1780-1790), ujawniało się w czasie rządów jego matki Marii Teresy (1743-1780), ale swój początek miało w rekatolicyzacji kraju

${ }^{2}$ Wizyty u papieża unikał także minister spraw zagranicznych Edvard Beneš, obaj podczas swych w Rzymie nie odwiedzili papieża choć Stolica Apostolska wyrażała życzenie takich spotkań. Por. M. Pehr, J. Šebek, Československo a Svatý stolec: od neprátelství ke spolupráci (1918-1928). I., Úvodni studie., Praha 2012, s.22-23.

${ }^{3}$ Por. M. Pehr, J. Šebek, Československo a Svatý stolec..., dz. cyt. s. 13-15. 
w XVII wieku. Tutaj warto zwrócić uwagę, że do dzisiaj w społeczeństwie czeskim przetrwały postawy i poglądy zbieżne z józefinizmem4

3) Popieranie przez hierarchię starego porządku; dotyczyło to także działań papieża Benedykta XV, którego inicjatywy pokojowe zmierzały do zachowania status quo, a więc podtrzymania Cesarstwa Austro-Węgierskiego ${ }^{5}$.

4) Brak identyfikacji tożsamości narodowej z Kościołem katolickim; jednocześnie jako głównego bohatera narodowego traktowano Jana Husa, księdza katolickiego, jednak na skutek XIX-wiecznej niereligijnej recepcji husytyzmu jego podglądy nie miały znaczenia ${ }^{6}$; nie istniały wtedy żadne struktury, które wywodziłyby swój rodowód z czasów Jana Husa (Kościół czechosłowacki przyjął określenie „husycki” dopiero w roku 1971).

5) Traktowanie Stolicy Apostolskiej jako źródła wpływów zewnętrznych. Nowa republika poszukiwała swojej tożsamości. Nowe struktury tworzono pod hasłem „Precz od Wiednia i od Rzymu”"

6) Niespełnienie oczekiwań tzw. katolickiej moderny (liturgia w języku narodowym komunia święta pod dwiema postaciami, oddawanie czci Janowi Husowi, udział świeckich w kierowaniu Kościołem, zniesienie celibatu) doprowadziło w końcu do powstania Kościoła czechosłowackiego ${ }^{8}$.

7) Znaczne wpływy ruchów socjalistycznych oraz stosunkowo duże wpływy partii lewicowych w pierwszych rządach Czechosłowacji. Ruchy te rozwinęły się w znacznym stopniu już w XIX wieku dzięki intensywnej industrializacji i urbanizacji ziem Korony Czeskiej'.

8) Poglądy religijne prezydenta Tomáša Garrigue’a Masaryka, który w nowym społeczeństwie pełnił nie tylko najważniejszą funkcję, ale jednocześnie był niekwestowanym i ważnym autorytetem moralnym ${ }^{10}$. Był człowiekiem religijnym, dla którego religia pełniła funkcje porządkującą w społeczeństwie. Ograniczał ją zasadniczo do moralności, widział możliwość godzenia religii z nauką i filozofią, zarazem wątpił w potrzebę istnienia struktur kościelnych. Uważał, że wiarę można przeżywać indywidulanie. Opuścił Kościół katolicki w wieku lat trzydziestu (1880),

\footnotetext{
${ }^{4}$ W okresie rządów komunistycznych oraz po rewolucji aksamitnej w 1989 roku duchowieństwo otrzymywało państwowe pensje i nie było to przedmiotem publicznej dyskusji. Ponadto w obu tych okresach duchowni pełnili funkcje ministerialne, a nauka religii formalnie była dozwolona w szkołach państwowych (w okresie komunizmu jednak wiązało się to z różnymi formami represji).

${ }^{5}$ Por. M. Pehr, J. Šebek, Československo a Svatý stolec, dz. cyt, s. 18-19.

${ }^{6}$ Por. H. Kaczmarek, Czechy. Kościót i państwo, Kraków 2016, s. 104-107.

${ }^{7}$ Por. M. Pehr, J. Šebek, Československo a Svatý stolec, dz. cyt., s. 53; zob. także J. Hanuš, dz. cyt., s. 44.

${ }^{8}$ Por. H. Kaczmarek, Czechy..., dz. cyt., s. 115-117 i 124-125.

${ }^{9}$ Por. H. Kaczmarek, Czechy..., dz. cyt., s. 107-109.

${ }^{10}$ Por. H. Kaczmarek, Czechy..., dz. cyt., s. 117-123.
} 
jednak i Kościele ewangelickim rzadko uczestniczył w nabożeństwach. Po pierwszej wojnie światowej miał konflikty z katolicką hierarchią, zwłaszcza przy okazji wprowadzania święta Jana Husa w 1925 roku (tzw. afera Marmaggiego).

\section{Druga niepodległość - 1989}

Nawiązując do wspomnianej wyżej odmiennej relacji do Kościoła katolickiego po przewrocie 1989 roku, należy spytać, co było powodem jego nowej afirmacji i prestiżu w społeczeństwie czeskim. Czemu prezydent Václav Havel na samym początku urzędowania zaprosił do Czech Jana Pawła II? Dlaczego zaskakująco wysoki procent czeskich obywateli Czechosłowacji deklarowało swoją przynależność do Kościoła katolickiego?

Nowe nastawienie do Kościoła katolickiego pojawiło się pomimo istnienia dawnych źródeł niechęci:

- w społeczeństwie czeskim nadal istniała akceptacja dla józefińskich metod (Kościół instytucją państwową, zgoda na pensje dla duchowieństwa, religia w szkole, ksiądz Petr Pit'ha ministrem w rządzie Václava Klausa),

- T. G. Masaryk był traktowany był wciąż jako wielki autorytet moralny i wzór w sprawowaniu rządów (nawiązywał do niego V. Havel, T. G. Masaryk do dzisiaj jest cytowany przez przedstawicieli różnych opcji politycznych), przetrwało przede wszystkim „masarykowe” przekonanie o możliwości prywatnego wyznawania wiary,

- Jan Hus stale był ważnym bohaterem narodowym,

- dla sporej części czeskiego społeczeństwa ważne były poglądy lewicowe, a przedstawiciele partii komunistycznej byli wybierani do parlamentu we wszystkich polistopadowych wyborach.

W czasie aksamitnej rewolucji nastąpił natomiast zanik znaczenia pozostałych czynników niecięci do Kościoła:

- na skutek cenzury i braku informacji w czasach komunizmu Stolica Apostolska stała instytucją odległą i nieznaną, niewywołującą konkretnych nastawień społeczeństwa; wieloletnie negocjacje w latach 1963-1989 nie przyniosły znaczących rezultatów,

- postulaty religijne tzw. moderny stały się nieaktualne - istniał Czechosłowacki Kościół husycki, po Soborze Watykańskim II niektóre postulaty były bezzasadne (liturgia w języku narodowym, komunia św. pod dwoma postaciami).

Zasadniczo pozytywne nastawienie wynikało z następujących czynników:

1) Kościół świadectwa. W społeczeństwie czeskim istniała pamięć o odważnym znoszeniu represji przez Kościół katolicki. Był on najbardziej prześladowaną instytucją w społeczeństwie, w którym na opór odważyli się tylko nieliczni. 
Trwanie pomimo prześladowań stało się źródłem szacunku. Swego rodzaju nobilitacją było przyznawanie się do tak szacownej i szlachetniej instytucji. Właśnie ta chęć partycypacji w tej instytucji się znalazła wyraz podczas spisu powszechnego w 1991 roku.

2) Pojawienie się ważnych osobistości, takich jak Václav Havel i kard. František Tomášek. Václav Havel był dysydentem, jednym z współtwórców Karty 77. Jako dramaturg w swoich tekstach krytykował rządy komunistyczne, stał się naturalnym kandydatem na prezydenta, wybranym w atmosferze rewolucyjnej jeszcze przez komunistyczny parlament. Václav Havel był katolikiem, ale praktycznie był agnostykiem. Najwięcej o religii napisał w więziennych Listach do Olgi, które w rzeczywistości były adresowane do grupy intelektualistów, uczestników tajnego seminarium, w większości katolików ${ }^{11}$. Jako niekwestionowany autorytet dla większości społeczeństwa, mógł szerzyć w nim swoje pozytywne nastawienie do chrześcijaństwa.

Kardynał František Tomášek był administratorem praskiej archidiecezji (19651977), a potem jej arcybiskupem (1977-1991); w pierwszym okresie sprawowaniu funkcji był zasadniczo ostrożny w krytykowaniu rządów komunistycznych; odważniej występował w drugim okresie (starał się o zlikwidowanie organizacji księży Pacem in terris; poparł petycję Augistina Navratila, w której domagano się swobód dla Kościoła ${ }^{12}$; w roku 1984 zaprosił Jana Pawła II na uroczystości z okazji 1100 rocznicy śmierci św. Metodego ${ }^{13}$; w listopadzie 1987 roku rozpoczął program Dziesięciolecia Duchowej Odnowy Narodu; 25 stycznia 1989 ogłosił odezwę do przedstawicieli Kościołów w Polsce, Niemczech, Austrii i na Węgrzech w celu tworzenia „europejskiego mostu modlitw”14, na początku 1989 r. potępił represje władz komunistycznych w stosunku do uczestników manifestacji).

Wydaje się, że duży wpływ na zmianę postawy kard. Tomáška miał kard. Karol Wojtyła ${ }^{15}$, który już w roku 1977 usilnie zachęcał go „do większej stanowczości wobec czechosłowackiego reżimu”" W dzień wyboru na Stolicę Piotrową Jan

${ }^{11}$ Por. H. Kaczmarek, Bóg prezydenta Havla, [w:] Wolność. Wieczne wyzwanie, red. B. Rydliński, S. Sowiński, R. Zenderowski, Warszawa 2018, s. 201-210.

${ }^{12}$ Por. B. Svoboda, Po stronie narodu. Kardynat František Tomášek w boju z reżimem komunistycznym (1965-1989), Kraków 2013, s. 212-213. Zob. także: G. Weigel, Świadek nadziei. Biografia papieża Jana Pawła II, Kraków 2000, s. 740-741.

${ }^{13}$ Por. B. Svoboda, Po stronie narodu, dz. cyt., s. 181.

${ }^{14}$ Por. B. Svoboda, Po stronie..., dz. cyt., s. 228-229.

${ }^{15}$ Por. G. Weigel, Świadek nadziei..., dz. cyt., s. 378-379; zob. także: G. Weigel, Kres i początek. Papież Jan Paweł II - zwycięstwo wolności, ostatnie lata, dziedzictwo, Kraków 2012, s.184-185 i 193.

${ }^{16}$ Por. B. Svoboda, Po stronie narodu, dz. cyt., s. 141. Rozmowa miała miejsce w Rzymie, w czasie synodu o wychowaniu religijnym. Podobny pogląd miał wyrazić również kard. Stefan Wyszyński. 
Paweł II zapewniał kard. Tomáška o swoim wsparciu i chęci pomocy ${ }^{17}$. Zapewne zachęty i poparcie Jana Pawła II wpłynęły na zmianę postepowania kard. Tomáška, ale nie były jedynymi czynnikami zmiany. Duże znaczenie miał też krąg współpracowników, który zgromadził się wokół praskiego arcybiskupa pod koniec lat siedemdziesiątych XX wieku. Byli to duchowni i świeccy, którzy go wspierali, inspirowali oraz przygotowywali potrzebne materiały do wystąpień publicznych i programów duszpasterskich.

Należy tu zaznaczyć, że czas szczególnego prestiżu Kościoła katolickiego nie był długim okresem, można go szacować najwyżej do roku $1993^{18}$. W tym roku miał już miejsce głośny spór o własność katedry praskiej, dyskusje wzbudzał akt zawierzenia narodu czeskiego Matce Bożej, rozpoczął się wieloletni spór o restytucję majątku kościelnego, w tym roku sekretariat stanu Stolicy Apostolskiej wezwał czeskiego ambasadora $\mathrm{w}$ celu omówienia nierozwiązanych spraw. Jeśli pozytywne nastawienie wynikało $\mathrm{z}$ odważnego znoszenia prześladowań $\mathrm{w}$ okresie niedawnego komunizmu, to można powiedzieć, że przejawiła się tutaj „krótka pamięć" niedawnej historii.

\section{Jan Paweł II i druga niepodległość}

Szczególnym wyrazem wpływu Jana Pawła II na zmiany w Czechosłowacji pod koniec lat 80. miało wyżej wspomniane inspirowanie kard. Františka Tomáška. Zapewne wpływ ten miał miejsce także poprzez udział papieża w obaleniu całego systemu komunistycznego w Europie Środkowej ${ }^{19}$. W tym miejscu warto zarazem przypomnieć przynajmniej niektóre przykłady szczerej życzliwości Karola Wojtyły - Jana Pawła II wobec Czechów i przejawy wspierania przez niego Kościoła na ziemiach czeskich, jeszcze w czasach, gdy był kardynałem w Krakowie, a także po wstąpieniu na Stolicę Piotrową. Działania te były pocieszeniem w trudnych czasach i realną pomocą w dążeniu do wolności. Oto niektóre z nich:

- tajne święcenia kapłanów w okresie rządów komunistycznych ${ }^{20}$,

- obecność na pogrzebie kard. Štěpána Trochty; w roku 1974 kard. Karol Wojtyła przybył do Czechosłowacji na pogrzeb kardynała Štěpána Trochty w Litomierzycach. Znakiem czasu był fakt, że obecni tam zagraniczni biskupi i kardynałowie nie mogli wziąć udziału w koncelebrze. Kardynał Stefan Wyszyński w ogóle nie dotarł na pogrzeb, bo nie wpuszczono go na teren Czechosłowacji i zawrócono

\footnotetext{
${ }^{17}$ Por. B. Svoboda, Po stronie narodu, dz. cyt., s. 143.

${ }^{18}$ Por. H. Kaczmarek, Czechy. Kościół i państwo, dz. cyt., s. 293-294.

${ }^{19}$ G. Weigel, Kres i poczatek..., dz. cyt., s. 204 i 479.

${ }^{20}$ Por. G. Weigel, Świadek nadziei..., dz. cyt., s. 298.
} 
na granicy. Wyrazem odwagi przyszłego papieża było wygłoszenie mowy nad grobem zmarłego kardynała i nazwanie go męczennikiem ${ }^{21}$. Słowa kardynała Wojtyły pozostały we wdzięcznej pamięci Czechów ${ }^{22}$.

- wyrazy solidarności przy okazji wizyt do sąsiednich krajów (Polska, Austria); podczas swojej pierwszej pielgrzymki do Polski w roku 1979 papież zauważył w Gnieźnie transparent: „Pamatuj otče svátý na své české děti”. Zareagował na niego słowami: „Nie może ten papież, który nosi w sobie spuściznę Wojciechową, zapomnieć tych dzieci! I nie możemy my wszyscy, Drodzy Bracia i Siostry, którzy nosimy to samo Wojciechowe dziedzictwo, zapomnieć tych naszych Braci!"23. W czasie pielgrzymki do Austrii w roku 1988 skierował pozdrowienie do pielgrzymów również w językach czeskim i słowackim. Dzięki transmisji Radia Wolna Europa czescy katolicy mogli się znowu przekonać o jego życzliwej pamięci.

- listy do czeskiego duchowieństwa (2 marca 1979 - z okazji 250-lecia kanonizacji św. Jana Nepomucena ${ }^{24} ; 19$ marca 1985 - z okazji 1100 rocznicy śmierci św. Metodego ${ }^{25}$ ) oraz przy okazji wizyty „Ad limina”26 (1987),

- kanonizacja św. Agnieszki Czeskiej (12 listopada 1989), do Rzymu przyjechało ok. 12 tys. pielgrzymów, było to wielkie doświadczenie wolności. Niektórzy łączyli rewolucję aksamitną i upadek komunizmu z kanonizacją św. Agnieszki. Nazywano to cudem św. Agnieszki ${ }^{27}$.

\section{Pielgrzymka na progu nowej niepodległości (21-22 IV 1990)}

Jan Paweł II przybył do Czechosłowacji zaledwie kilka miesięcy po aksamitnej rewolucji (17 listopada 1989), miało to miejsce w okresie entuzjazmu z powodu odzyskania wolności i w czasie szczególnie wysokiego prestiżu Kościoła katolickiego w Czechosłowacji. Była to czterdziesta szósta podróż papieża z Polski. Jan Paweł II przyjechał do wolnej Czechosłowacji na zaproszenie niedługo przedtem wybranego prezydenta Václava Havla. Nowy czechosłowacki prezydent wysłał zaproszenie w dzień wybrania go na najważniejszą funkcję w państwie (29 grudnia 1989). Papież przybył jak najszybciej, bo w pierwszy swój wolny weekend

${ }^{21}$ Por. G. Weigel, Świadek nadziei..., dz. cyt., s. 233 i s. 286.

${ }^{22}$ Por. B. Svoboda, Po stronie narodu..., dz. cyt., s. 116-117.

${ }^{23}$ Por. Jan Paweł II, Musicie od siebie wymagać, Poznań 1984, s. 52.

${ }^{24}$ Por. G. Weigel, Świadek nadziei..., dz. cyt., s. 378.

${ }^{25}$ Por. G. Weigel, Świadek nadziei..., dz. cyt., s. 634.

${ }^{26}$ Por. H. Havlíčková, Dédictví. Kapitoly $z$ dějin komunistické perzekuce v Československu 1948-1989, Olomouc 2002, s. 364-365.

${ }^{27}$ Por. M. Vlk, Czy Europa stanie siępogańska? Miloslav Vlk w rozmowie z Rudolfem Kuczera, Kraków 2002, s. 17, 19; zob. także. G. Weigel, Ostateczna rewolucja: Kościót sprzeciwu a upadek komunizmu, Poznań 1995, s. 242. 
po aksamitnej rewolucji (tydzień po Wielkiej Nocy). Na lotnisku prezydent Havel witał papieża pamiętnymi słowami: „Nie wiem, czy wiem, co to jest cud. Mimo to ośmielam się powiedzieć, że jestem w tej chwili uczestnikiem cudu"28. Według Havla cudem był fakt, że ten, kto pół roku wcześniej był uważany za wroga państwa może jako prezydent witać pierwszego w historii papieża, który stanął na terenie tego państwa. Czechosłowacki prezydent nazwał papieża posłem miłości, pokoju, dialogu, wzajemnej tolerancji, a także symbolem nauki i zwiastunem braterskiej jedności w różnorodności ${ }^{29}$. W odpowiedzi papież przyznał się do pragnienia przyjazdu do Czech już pięć lat wcześniej. Na początku swojej wizyty przypomniał, że starał się być ustami Kościoła w Czechosłowacji wtedy, gdy był on zmuszony do milczenia. Oświadczył wtedy także, że chce zachęcić wierzących do udziału w rozwiązywaniu problemów społeczeństwa, które wkroczyło na drogę wolności ${ }^{30}$. Wyraził też wówczas uznanie dla dzieł związanych ze św. Wojciechem: Dziesięciolecia Duchowej Odnowy Narodu i „modlitewnego mostu”, który łączył kraje związane z dziedzictwem św. Wojciecha. Prosto z lotniska Jan Paweł II udał się do katedry św. Wita na spotkanie z duchowieństwem oraz osobami niepełnosprawnymi. Podziękował tam księżom i świeckim za wierność Ewangelii oraz za jedność ze Stolicą Piotrową nawet w czasie, gdy czeskie diecezje pozbawione były biskupów. Zachęcił również do uczestniczenia w przemianach, jakie dokonywały się w Czechosłowacji ${ }^{31}$. W pierwszy dzień wizyty papież odprawił jeszcze mszę św. na Letnej, gdzie przypomniał trudne czasy prześladowań komunistycznych. W drugim dniu swojej pierwszej wizyty w Czechosłowacji Jan Paweł II odwiedził Velehrad i Bratysławę.

\section{Przesłanie papieskich pielgrzymek do Czech}

Jan Paweł II odbył trzy pielgrzymki do Czech w latach 1990, 1995, 1997. Pierwsza odbyła się w warunkach tworzenia się nowego państwa, okazją do drugiej była kanonizacją św. Zdzisławy i św. Jana Sarkandra, natomiast trzecia się była związana $\mathrm{z}$ tysięczną rocznicą śmierci św. Wojciecha. Jako przesłanie tych pielgrzymek zapewne można wskazać następujące idee:

1) Ewangeliczne świadectwo. Za André Frossardem można powiedzieć, że Jan Paweł II przyjeżdżał do Czech jako papież z Galilei ${ }^{32}$. Wypada tu przytoczyć zdarzenia z drugiej pielgrzymki Jana Pawła w 1995 roku, gdy w Ołomuńcu miały od-

\footnotetext{
${ }^{28}$ Por. G. Weigel, Świadek nadziei, dz. cyt., s. 771.

${ }^{29}$ Por. Návštěvy Jana Pavla II. u nás, Kostelní Vydří 2007, s. 9.

${ }^{30}$ Por. Návštěvy Jana Pavla II..., dz. cyt., s. 10-11.

${ }^{31}$ Por. Návštěvy Jana Pavla II..., dz. cyt., s. 14-16.

${ }^{32}$ Por. A. Frossard, „Nie lękajcie się”. Rozmowy z Janem Pawłem II, Watykan 1982, s. 7.
} 
być się uroczystości kanonizacyjne św. Jana Sarkandra. Wzbudzały one pewne napięcie, ponieważ ewangelikom nie podobało się wyniesienie na ołtarze człowieka zaangażowanego $\mathrm{w}$ spory międzywyznaniowe. Papież zareagował na te napięcia w sposób ewangeliczny - w imieniu Kościoła katolickiego w Czechach przeprosił za krzywdy wyrządzone niekatolikom i zarazem wybaczył winy wyrządzone Kościołowi przez niekatolików. Wydaje się, że dzięki temu w roku 1997, w czasie trzeciej pielgrzymki do Czech, przewodniczący czeskiej rady ekumenicznej Pavel Smetana witał papieża, jako „brata Jana Pawła”. Święty papież pokazał tym gestem, że przebaczenie może prowadzić do pojednania. Jan Paweł II dążył konsekwentnie do pojednania z ewangelikami i ewangelicką częścią czeskiej tradycji. Występował tu bardziej jako świadek niż nauczyciel.

2) Wezwanie do przemyślenia dziedzictwa Jana Husa. Impuls do nowego określenia dziedzictwa Jana Husa dał papież Jan Paweł II w czasie swojej pierwszej pielgrzymki do Czechosłowacji, gdy zachęcił do zrewidowania postawy w stosunku do XV-wiecznego teologa ${ }^{33}$. Przypomniał wtedy słowa kard. Berana z ostatniej sesji Soboru Watykańskiego II o przykrych konsekwencjach spalenia na stosie Jana Husa ${ }^{34}$. Papież zachęcał tam czeskich teologów do nowego określenia miejsca Jana Husa wśród reformatorów Kościoła, zarazem sam wskazał na nieskazitelność jego życia i jego starania o pogłębienie wiedzy i moralności narodu czeskiego. W odpowiedzi na wezwanie papieża w roku 1993 odbyła się konferencja w niemieckim Bayreuth na temat Jan Hus między epokami, narodami i wyznaniami. W tym samym roku abp Miloslav Vlk powołał komisję do zbadania życia i dzieła Jana Husa. Tworzyli ją katolicy, ewangelicy oraz naukowcy z kilku czeskich uczelni. Prace komisji zakończyła międzynarodowa konferencja naukowa, która odbyła się na Uniwersytecie Laterańskim w Rzymie w dniach 15-18 grudnia $1999 \mathrm{roku}^{35}$. Uczestnicy konferencji omówili życie mistrza Jana Husa, jego dzieło i epokę, w której żył. Nie ogłoszono tam ostatecznej teologicznej oceny jego poglądów, nie stwierdzono ani jego błędów, ani z błędów go nie oczyszczono. Wspólne oświadczenie kardynała Miloslava Vlka i przewodniczącego czeskiej Rady Ekumenicznej Pavla Smetany wydane po konferencji było pełne pochwał dla ewangelicznego życia mistrza Jana, konstatowało ono prekursorski charakter jego nauki oraz zawierało wezwanie do chrześcijan różnych wyznań,

${ }^{33}$ Por. Návštěvy Jana Pavla II..., dz. cyt., s. 25-26.

${ }^{34} \mathrm{Na}$ ostatniej sesji Soboru Watykańskiego II kard. Józef Beran powiedział: „Kościół katolicki w mojej ojczyźnie zdaje się cierpieć karę za te winy i błędy, które czynione były w jego imieniu przeciwko wolności sumienia, jak np. spalenie księdza Jana Husa lub przymus zewnętrzny dla ponownego przyjęcia wiary katolickiej, który był stosowany w XVII stuleciu wobec narodu czeskiego". Cyt. za: E. W. Böckenförde, dz. cyt., s. 60.

${ }^{35}$ Por. Jan Hus ve Vatikánu, Mezinárodní rozprava o českém reformátoru 15. století a o jeho recepci na prahu třetího tisíciletí, red. J. Pánek, M. Polivka, Praha 2000. 
by spory teologiczne nie powodowały już nigdy pełnych nienawiści konfliktów religijnych. Wyrazem znaczenia konferencji dla państwa czeskiego był udział w niej prezydenta Václava Havla, który w swoim przemówieniu zwrócił uwagę na stałe dążenie mistrza Husa do prawdy, jego kierowanie się sumieniem i zasadą osobistej odpowiedzialności. Na wymowę konferencji i jej przyszłe oddziaływanie na pewno znaczący wpływ będą miały słowa Jana Pawła II wypowiedziane do jej uczestników:

Dzisiaj, w przeddzień Wielkiego Jubileuszu, uważam za swój obowiązek wyrazić głębokie ubolewanie z powodu okrutnej śmierci zadanej Janowi Husowi oraz głębokiej rany, jaka w jej następstwie otwarła się w umysłach i sercach Czechów, stając się przyczyną konfliktów i podziałów. ${ }^{36}$

3) Milczenie w sprawie konkordatu. W czasie swoich pielgrzymek do Czech Jan Paweł II nigdy publicznie nie wypowiadał się na temat umowy konkordatowej ${ }^{37}$. Republika Czeska jest w tym względzie wyjątkowa - wciąż de facto nie posiada takiej umowy, chociaż jest ona standardem w relacjach ze Stolicą Apostolską. Po negocjacjach, które odbywały się w latach 2000-2002 umowa konkordatowa została wprawdzie podpisana przez czeskiego ministra spraw zagranicznych i sekretarza stanu Stolicy Apostolskiej. Do dzisiaj jednak nie została ratyfikowana. Jej postanowienia w pewnym sensie obowiązują, bowiem na mocy Konwencji wiedeńskiej o prawie traktatów z roku 1969 (art. 18) Republika Czeska nie może tworzyć norm prawnych, które byłyby sprzeczne z treścią podpisanej Umowy ${ }^{38}$.

Można sądzić, że to milczenie w sprawie konkordatu wynikało z przekonania o tym, że pomimo trudnej przeszłości Kościół w Republice Czeskiej ma możliwość funkcjonowania. Wydaje się, że wyjaśnieniem braku wypowiedzi w tej kwestii jest główne przesłanie pontyfikatu Jana Pawła II, które zawarł w swojej pierwszej en-

${ }^{36}$ Por. Jan Paweł II, Prawda, która wyzwala. Do uczestników sympozjum naukowego poświęconego Janowi Husowi, http://www.opoka.org.pl/biblioteka/W/WP/jan_pawel_ii/ przemowienia/hus_17121999.html (1.2.2014).

${ }^{37}$ W roku 1997 na spotkaniu z Episkopatem mówił o zwrocie majątku kościelnego, o potrzebie negocjacji w ramach kościelno - państwowej komisji. Por. Návštěvy Jana Pavla II..., dz. cyt., s. 88-89.

${ }^{38} \mathrm{~W}$ roku 2008, w ramach prac nad nowelizacją kodeksu prawa cywilnego, proponowano wprowadzenie obowiązkowego ślubu cywilnego, co było sprzeczne projektem Umowy konkordatowej. Później zrezygnowano z takiej zmiany i ślub kościelny jest stale alternatywną, uznawaną przez państwo, formą zawarcia związku małżeńskiego. Por. Stát chce zrušit církevní sňatky, bije na poplach europoslankyně Roithová, http://zpravy.idnes.cz/stat-chce-zrusit-cirkevni-snatky-bijena-poplach-europoslankyne-roithova-15k-/domaci.aspx? c=A080909_185804_domaci_adb (7.2.2015). 
cyklice Redemptor hominis, a przypomniał w czasie spotkania z ludźmi kultury w pałacu prezydenckim w roku 1990:

Chrystus przeto również i dziś, po dwóch tysiącach lat, staje wśród nas jako Ten, który przynosi człowiekowi wolność opartą na prawdzie, który człowieka wyzwala od tego, co tę wolność ogranicza, pomniejsza, łamie u samego niejako korzenia, w duszy człowieka, w jego sercu, w jego sumieniu. (RH 12) $)^{39}$

Tutaj Jan Paweł II pokazał, że skupia się na tym, co istotne w posłaniu Kościoła, a więc na głoszeniu Ewangelii. Braki w sferze rozwiązań instytucjonalnym nie mogą powstrzymywać przed skupieniem się nad tym, co naprawdę jest ważne.

\section{Podsumowanie}

1) Kościół katolicki w Czechach miał odmienną pozycję w momencie powstania Republiki Czechosłowackiej w roku 1918 i 1989.

2) Odmienność wynikała przede wszystkim z pojawienia się „Kościoła świadectwa" oraz szczególnych indywidualności w osobach Václava Havla i kard. Františka Tomáška, na którego wpływ miał Jan Paweł II poprzez własny przykład i słowa zachęty.

3) Jan Paweł II jako papież odbył trzy pielgrzymki do Czech (1990, 1995, 1997). Przybywał tam jako „papież z Galilei”: głosił Ewangelię, kanonizował świętych, był świadkiem przebaczenia i pojednania.

Jego głoszenie przemieniało również oblicze Czech.

\section{Abstract \\ Czechoslovakia and the Czech Republic. \\ Two independences and John Paul II}

The article describes different attitudes of the Czech population towards Catholic Church in the years of 1918 and 1989. At the time of the formation of the Czechoslovac Republic after the First World War, the Church was basically negatively valued by most of the society because of its long-lasting links with the Habsburg monarchy. In the year of 1989, the Church was relatively highly valued by the society although religiosity as such had declined significantly as compared to that of the year 1918. This new attitude in the

\footnotetext{
${ }^{39}$ Por. Návštěvy Jana Pavla II..., dz. cyt, s. 24.
} 
society came from the Church's courage in bearing persecutions during the Communist regime.

The article also describes the contacts of John Paul II with Czechoslovakia and the way he inspired Cardinal František Tomášek (the Archbishop of Prague and Czech Primate) to stand up with courage in the face of the communist regime. Cardinal Tomášek supported Czechoslovac dissidents and this - together with the criticism of government and the finding of new ways in pastoral field-was a source of prestige for the Catholic Church after the fall of communism. Unfortunately, this positive attitude lasted only for several years.

Keywords: history of Czechoslovakia, John Paul II, František Tomášek, velvet revolution, Church and the politics 